\title{
REVIEW
}

\section{DER ER FEDTEDE FINGERAFTRYK OVERALT PÅ TAL Introduktion til Helen Verrans bog (2001) Science and an African Logic ${ }^{1}$}

\section{NATHALIA BRICHET OG BRIT ROSS WINTHEREIK}

Det er en fælles begejstring for bogen Science and an African Logic (Verran 2001), der har ført til ønsket om at præsentere den for et dansk publikum. I stedet for et format, hvor vi som distancerede og vurderende anmeldere fremhæver positive og negative træk ved bogen, har vi baseret vores introduktion på to samtaler med forfatteren for på den måde at komme i dialog med Helen Verran om bogens tilblivelse, dens indhold og analytiske konsekvenser.

Den første samtale fandt sted på Hotel Opera i København i forbindelse med Helen Verrans besøg på Danmarks Pædagogiske Universitet og på IT-Universitetet i efteråret 2009. Den anden samtale fandt sted i januar 2010 på Verrans kontor på Melbourne Universitet. Her arbejder hun på afdelingen for filosofi og antropologi. Vores tilgang er således i tråd med en opfattelse, der kommer til udtryk i samtalerne med Helen Verran og i hendes bog: at god akademisk praksis handler om at være til stede, hvor tingene sker, for eksempel i konkrete møder mellem verdener, der måske, måske ikke, har noget at sige hinanden.

\section{Bogens tilblivelse}

Arbejdet med Science and an African Logic begynder i midten af 1980'erne. Sammen med sin mand, der som hun har en ph.d.-grad i biokemi, rejser hun til Nigeria, hvor hun kommer til at arbejde med efteruddannelse af nigerianske matematiklærere. Til sin overraskelse finder hun antropologisk litteratur i en boghandel i Yorubaland. Blandt andet finder hun Robin Hortons berømte artikler om traditionel afrikansk tænkning og vestlig videnskab, hvori han argumenterer for, at der findes en ,afrikansk logik“, der fungerer som et lukket system og derfor er ude af stand til at ændre sig. Dette system modstiller Horton en vestlig, videnskabelig tankegang, der, som Horton siger - i modsætning til den afrikan- 
ske - netop er kendetegnet ved at kunne forandre sig, når den overbevises af en virkelig, det vil sige universel, sandhed.

„Jeg blev rasende over dette udslag af rendyrket universalisme," fortæller hun kun en smule formildet af de 20 år, der er gået, siden hun læste Horton. Hun opdagede dog snart, at den modsatte position - argumentet for en radikal relativisme - var ikke bare nært beslægtet med, men mindst lige så tvivlsom som universalismen.

Helen Verran: „Den konkrete måde at føre diskussionen om forholdet mellem en universel rationalitet og en partikulær relativisme på, som jeg stødte på i Yorubaland, var for længst passé inden for antropologien." Ikke desto mindre var det den diskussion, der antændte det raseri (,white rage“), der gjorde hende i stand til at skrive bogen, der imidlertid endte med at være 10 år undervejs.

På trods af tidens trends inden for antropologien bliver spørgsmålet om, hvorvidt den menneskelige tanke arbejder ud fra en universel logik eller fungerer ud fra uforenelige, kulturspecifikke relative logikker, Helen Verrans faste følgesvend i arbejdet med det nigerianske skolevæsen.

Det var en meget optimistisk tid i Nigeria. Biafrakrigen er overstået, der er masser af penge og lyst til uddannelse, der er den stemning af, 'ja, vi kan gøre det, vi er kommet af med vores diktatur, vi har haft vores borgerkrig, vi har alle disse penge [fra olie, red.], vi bliver et godt uddannet samfund.' Folk tror virkelig på den kraft, der ligger i uddannelse. Jeg har været lærer hele mit liv, så at være i et land med så mange mennesker og $\mathrm{i}$ en så turbulent tid, hvor alle er sikre på, at uddannelse er svaret, det er virkelig vidunderligt og passer godt med mine værdier. Uddannelse og læring kan forandre, eller rettere forandrer, folk individuelt og forandrer samfund, og hvis vi er reflekterede omkring det og gør ting i en god tro, så vil det ske.

Helen Verran læner sig tilbage i stolen, holder en kort pause og fortsætter så:

Så vi står over for en idealistisk kvinde, virkelig meget en lærer, det skal vi ikke glemme, denne tro, og virkelig at ville forandre måden, folk gør ting og verden på. Det lyder skørt nu, men det lød ikke så skørt dengang.

Drevet af optimisme gør Helen Verran således en indsats for at undervise de nigerianske lærere i vestlige læringsmetoder og -standarder inden for matematik. Hun er overbevist om, at denne viden vil ruste dem til at undervise en ny generation af børn i Nigeria. Lidt drilsk kan man spørge, om ikke Helen Verrans raseri over universalismens arrogance kan genfindes i en mere positiv og inkluderende form i denne optimistiske uddannelsesiver (en uddannelse efter de tidligere koloniherrers model). Den universalisme, der ligger til grund for udarbejdelsen af uddannelser, bliver Helen Verran dog mere og mere kritisk over for i løbet af sine år i Nigeria. 


\section{„Indviklet i relativismen“}

Arbejdet med matematiklærerne nærer Helen Verrans filosofiske interesser, hvilket man kan læse om i Science and an African Logic, der er delvist selvbiografisk, i den forstand at hun undervejs tager sin egen forståelse op til revision. Bogen følger Helen Verran på hendes rejse væk fra en relativistisk kritik af den universalisme, der placerer vestlig og ikke-vestlig viden hierarkisk i forhold til hinanden. Når den vestlige tradition påkalder sig universalitet, bliver den dermed også den målestok, som andre talforståelser dømmes ud fra. De andre talforståelser vil således i den universalistiske optik altid fremstå som primitive afarter eller dårlige kopier af det vestlige talsystem. Det bør understreges, at ideen om en universel målestok er en generel pointe for Helen Verran, som hun i dette tilfælde diskuterer via et fokus på talsystemer. Tal bliver den prisme, hvorigennem argumenterne træder frem, og dermed handler bogen om meget andet end tal. I de første udkast til bogen analyserer Helen Verran forskelle mellem yoruba og et vestligt talsystem og placerer sig inden for en relativistisk tradition, der fremstiller de to logikker som forskellige, men ligeværdige, for netop at gøre op med en universalistisk målestok. Undervejs i skriveprocessen finder hun imidlertid ud af, at hendes relativistiske tilgang ikke hænger sammen med den virkelighed, hun oplevede i klasseværelserne, dengang hun underviste de nigerianske matematiklærere, og hvor de siden underviste børn i matematik. Hun begynder derfor at genoverveje sine relativistiske analyser for undervejs i skriveforløbet at udvikle en tilgang, som med udgangspunkt i en anerkendelse af et kropsliggjort ,her og nu“ som stedet, hvor viden (om blandt andet tal) bliver til, fokuserer på, hvordan tal gør en forskel, hvordan de bliver praktiseret og er performative i konkrete sociale sammenhænge. Dette leder til bogens sidste kapitel, hvor Helen Verran udlægger sin praksisontologi, der forklarer tal, kroppe og andre enheder som objekter, der bliver til gennem deres interaktion med hinanden og med de steder, interaktionen foregår.

Centralt i bogen står historien om mr. Ojo, som er en af de skolelærere, Helen Verran superviserer i Nigeria. Mr. Ojo skal undervise børnene i længde, men i stedet for at fremstille længde som en udstrakt linje målt med et målebånd, bruger $\mathrm{mr}$. Ojo et stykke snor og et lille $10 \mathrm{~cm}$ langt papstykke. Længde bliver i mr. Ojos hænder til et lille bundt snor viklet i ringe rundt om papstykket, næsten som et garnnøgle. „Længde“ som universelt fænomen - noget, der er udstrakt mellem to punkter - bliver relativeret til en masse små delelementer, afhængigt af hvor mange gange snoren runder pappets kanter. I Helen Verrans hænder bliver historien om mr. Ojo en fortælling om, hvordan tal på den ene side gør os til dem, vi er, og på den anden side gøres af os.

Måden, mr. Ojo fremstiller længde på, forbløffer hende. ,Jeg tror, at jeg er afhængig af forbløffelse," siger hun og fortæller videre, at selv om børnene i mr. 
Ojos klasse lærer om længde, foregår det ikke på den måde, hun havde forestillet sig, det skulle gøres, og ikke på den måde, hun havde undervist mr. Ojo i at undervise. Metoden fungerer alligevel fremragende, faktisk bedre, end når de lærere, Helen Verran superviserer, følger hendes råd om at arbejde med længde som udstrækning ved hjælp af en snor. Mr. Ojos snore og papstykker gør børnene entusiastiske, og hurtigt er de i gang med at måle hinanden og deres omgivelser. Uden for skolen støder Helen Verran på børn, der ved hjælp af mr. Ojos metode står og måler de yams, de sælger fra en lille bod i vejkanten. Selv om mr. Ojos undervisning virker uhensigtsmæssig i forhold til børnenes indlæring ud fra et vestligt talsystem, giver den særdeles god mening for børnene, der tydeligvis engageres af kreativiteten med snore og papstykker. Umiddelbart ser det ud, som om metoden til at måle en hel længde (genstandens/personens fulde længde) via et særligt antal delelementer (antal gange snoren vikles om pappet) passer særdeles godt til et yoruba talsystem. I bogens relativistiske kapitler udlægger Helen Verran netop en af forskellene mellem yoruba og vestlig talforståelse som en forskel i forholdet mellem del/helhed og en/mange.

Men hvad skal hun gøre med denne viden om to talforståelser, der er et skoleeksempel på relativisme? Skal hun anbefale, at man laver to separate læseplaner, så børnene for eksempel om formiddagen vil blive undervist i yoruba matematik og om eftermiddagen i vestlig matematik? Skal hun virkelig anbefale et sådant apartheid - en udgrænsning af yoruba talsystemer fra vestlige talsystemer og vice versa? Og på et mere generelt niveau, hvad skal man stille op med forskelle?

Disse spørgsmål besvares i bogen - om end indirekte. Helen Verrans holdning er den, at det er dybt problematisk, når der trækkes faste grænser mellem forskellige praksisser og logikker, og de kommer til at fremstå som separate og uforenelige. Kritikken rettes på den måde både imod relativisme og universalisme, idet begge positioner afholder sig fra at ,røre ved verden“ og blive ,rørt af den". Om end de to positioner har hver sit ideologiske udgangspunkt, opererer de begge med givne forskelle. Hvor relativismens forskelle gives af historiske of sociale omstændigheder, gives universalismens forskelle af sandhed. Fælles for de to positioner er således, at forskelle findes derude. I relativismen er det uladsiggørligt at scette forskelle - forskelle er allerede givet og bør bevares som sådanne. I universalismen er der kun én forskel, den sande, grundlæggende forskel, og hvor alt uden for denne er dårlige efterligninger eller kopier.

Om bogen siger Helen Verran:

Den kan virke vanskelig, fordi det er tal, der driver og er resultatet af den forskelssætten, jeg interesserer mig for i bogen. De fleste mennesker, der er interesseret $\mathrm{i}$ forskel, de er interesseret $\mathrm{i}$ folk, ord, kultur osv. Og så kommer jeg og siger 'Kig også lige på tal'. Tal bringer mange læsere ud af deres 
bekvemmelighedszone. De er måske endda tidligere flygtet fra tal, så at være den, der kommer og siger, at nu skal de også forstå tal, det er en udfordring.

Vi spørger hende, om hun elsker tal: ,Ja, det gør jeg nok. Jeg elsker også andre entiteter, for eksempel mennesker, men bestemt også tal." Ifølge Helen Verran er kærligheden til tal nok mest at finde blandt logikere eller matematikere, som godt kan lide den slags renhed, tal kan give i deres egenskab af abstrakte symboler. Selv holder hun af tal, fordi, som hun siger: „Det eneste, jeg kan se, er rod. Tal prcesenterer sig som det mest universelle af universalier, som det simpleste og reneste universelle, der eksisterer, men der er fedtede, menneskelige fingeraftryk overalt på tal.“

\section{Metafysik „på farten“}

Et centralt spørgsmål for Helen Verran er således, hvordan vi som forskere undgår en snæversynet forståelse af, hvad ,forskel“ er. At interessere sig for forskel involverer ifølge Helen Verran en interesse for metafysik. I den teoretiske filosofi er metafysik det, der ligger uden for den empiriske verden, det vil sige uden for det, vi som mennesker har adgang til via vores sanser. For Helen Verran er metafysik derimod at forstå de forhold mellem kroppe, materialitet, teorier, abstraktioner, symboler, genstande osv., der udfolder sig i konkrete situationer. Metafysik er altså ikke noget, man får kendskab til fra en fjern, filosofisk position. I bogen udtrykker Helen Verran det således:

Min påstand er, at $\mathrm{i}$ forbindelse med en generativ kritik behøver vi en ny historie om det virkelige [realness], om hvordan og hvor det virkelige [realness] kommer fra. Et sådant projekt vil ikke fornægte sine forudsætninger, det vil vedkende sig sin metafysik. Sagt på en anden måde vil jeg sige, at vi bliver nødt til fuldstændigt at gentænke ontologiprojektet (Verran 2001:33).

Helen Verrans alternativ til en filosofi, der beskriver og vurderer verden fra en tilbagetrukket position, er en opfordring til forskere om at engagere sig i, hvad hun kalder „metafysik på farten“" (metaphysics on the run). Konkret indebærer dette en forståelse af, at „ord ikke er væsensforskellige fra fingre“. Grænserne mellem ord, tal, kroppe, lyde og andre objekter i verden skabes i konkrete situationer - viden, begreber og videnskabelse er således ikke adskilt fra handlinger i verden, men bliver til gennem handlinger i verden.

Helen Verran:

Man kan sige at viden opstår [emerges] fra vores fingerspidser, idet vi bliver opmærksomme på vores fingerspidser og på resten af vores kropsliggjorte væren. 
Dermed ender vi med et 'her og nu'. Jeg mener imidlertid også, at det er vigtigt ikke at sige, at denne form er den eneste viden, der findes. Det er klart. I ved, den her vision om videnskaben som universel, den forsvinder jo ikke, men vi må se på, hvordan de forskellige former sameksisterer og blive bedre til at forholde os til spændinger mellem dem.

Det er vigtigt at fastslå, at når Helen Verran taler om fingerspidser og om den viden, der opstår i fingres samspil med andre ting i verden, forsøger hun ikke at udgrænse eller privilegere sanselig viden fra diskursiv viden. Tværtimod fastholder hun - $\mathrm{i}$ tråd med andre positioner inden for videnskabsfilosofi som for eksempel aktørnetværksteori - at det diskursive og det materielt sanselige ikke kan adskilles forud for en analyse. For Helen Verran er ordene, tankerne og teorierne altid og allerede af verden. En analyse er med andre ord en bearbejdning af verden, der foregår i mødet med de fænomener, der undersøges. Teori og metode er ikke noget, der tilføres den empiriske verden fra en position uden for empirien - netop fordi empiri ikke findes. Helen Verrans metafysik er nært beslægtet med det, Bruno Latour i sin seneste bog The Making of Law: An Ethnography of the Conseil d'Etat kalder for empirisk filosofi, og ligger også tæt op ad Annemarie Mols begreb om praxiografi fra The Body Multiple (2002).

\section{Perspektiver og positioner}

Hvilke perspektiver tilbyder bogen i forhold til, hvordan vi som forskere kan blive bedre til at undersøge verden i betydningen bearbejde den?

Helen Verran fortæller, hvordan hun i akademiske sammenhænge er blevet kritiseret for ikke at redegøre nok for sin metode. Selv om hun nyder anerkendelse for sit arbejde i både Europa og USA, finder kritikere, at bogen er for tynd etnografisk set. Ifølge Helen Verran skyldes dette, at kritikerne læser for eksempel mr. Ojo-historien som en slags rå data, der gennem akkumulering af endnu mere data skal tjene som evidens for, at hendes analyse er sand. Helen Verrans analyser tager imidlertid afstand fra en idé om, at „empirien“ eller „det derude“ har en given form, der kan findes eller indsamles. Ifølge hende består verden ikke af partikulære entiteter, der abstraheres og generaliseres for gennem analyse at blive til genstande for en overordnet, generel teori. For Helen Verran udtrykker mr. Ojo en teori ganske på linje med de teorier, hun har med i bagagen. Begge skaber og fordeler verden på bestemte måder, der kun kan analyseres ved at anerkende et „her og nu“ (frem for et „,der og dengang“). De tekster og de praksisbeskrivelser, man som forsker trækker på i sit arbejde, er således på hver deres måde ressourcer for forskerens kreative skabelse af forskel i en konkret situation, hvor virkeligheder opstår. 
Vi har gjort et forsøg på at videregive vores begejstring for Helen Verrans arbejde. Vi har fundet hendes nysgerrighed og den gode portion mod, det kræver ikke blot at „,nøjes“" med at kaste sig over de efterhånden klassiske opgør med subjekt/ objekt, natur/kultur, givne/artificielle, men i stedet tage fat på de mere sejlivede dikotomier som abstrakt/konkret, partikulær/general og unik/universel, vældig inspirerende. Det kræver mod at problematisere den forståelse af viden, der er dominerende i vestlige samfund. Vi finder den et hav af steder. For eksempel i de evalueringspraksisser, der er blevet så udbredte, og hvor opfattelsen er, at man ud fra tilpas mange observationer af enkelttilfælde kan ekstrapolere generelle kategorier efter devisen ,jo flere, jo bedre“, (altså ud fra en idé om, at ophobning fører til sikker viden). Når evalueringen bedømmes, vil der blive spurgt til, om der er tilstrækkelig evidens for den generelle kategori - kan empirien bevise teorien? I denne forståelse, der står i stærk kontrast til den position, Helen Verran er fortaler for, sker der det, at når empirien bliver til eksempler på teorien, bliver forskeren/evaluatoren samtidig gjort til en tilbagetrukket og dømmende observator og autoritet, der hverken risikerer sin egen position eller at blive rørt af verden. Det er en position, hvorfra det er umuligt at vide noget om de grundlæggende antagelser, for eksempel om, hvilke forskelle i den praksis, der undersøges, der betyder noget. Det er en position, der gør det umuligt at blive rystet eller forbløffet. Evaluatorens troværdighed afhænger suverænt af, hvor godt det lykkes at holde det partikulære adskilt fra det generelle domæne, men dermed mister han/hun også muligheden for at lave en rigere og derfor mere brugbar analyse af den praksis, der undersøges. Konsekvensen er, at forskelle og forskelssætten - Helen Verrans undersøgelsesfelt - kun kan tillades ,,i det abstrakte“, det vil sige i sprog, tanker, symboler og diskurser, men ikke i de klasseværelser, hvor der undervises og evalueres. Og dette er problematisk, fordi man dermed også afgiver muligheden for bevidst at skabe forskelle i hverdagssituationer - både muligheden for at undervise i tal på forskellige måder i nigerianske klasseværelser og for på konstruktiv vis at analysere forskelle mellem yoruba og et vestligt talsystem.

\section{Nye studieobjekter: Skærme, handel med vand, kulturarv og informationsteknologi}

Siden Helen Verran kom tilbage til Australien, har hun beskæftiget sig med de indfødte australieres talsystemer, jordrettigheder og miljøpolitik. Hun har deltaget $i$ at oprette et projekt - Learning From Country - hvor stammeældste blandt yolgnu gav fjernundervisning til studerende på universitetet i Darwin. Med projektet ønskede Helen Verran og hendes kollega Michael Christie at bistå de indfødte australiere i at fortælle om deres tilknytning til jorden. Projektet valgte 
at synliggøre nogle af de mange udfordringer, der kan være, ved at samarbejde ved hjælp af ny teknologi til afsides egne. Sand føg ind i computerne, og der var ikke altid satellitforbindelse - vitale dele af fjernundervisningen. Når videokonferencerne lykkedes, var det til gengæld medrivende for deltagerne, og Helen Verran arbejder nu med, hvordan man kan forstå skærme og det at samarbejde gennem skærme fra en praksisontologisk position.

Ud over samarbejdet med yolgnufolket har hun i de senere år været optaget af markedsgørelsen af Australiens naturressourcer, heriblandt spørgsmål om vand, som i stigende grad er en knap ressource på det store kontinent. Hun har beskrevet indsamlingen af viden om vandressourcer ude ved Australiens små billabongs (vandløb), hvordan ngo'er og autoriserede aktører deltager, hvordan deres viden klassificeres og lagres i databaser, og hvordan den kommer til at spille en rolle i politiske beslutningsprocesser.

Tydeligvis favner Helen Verran selv bredt, og selv om vi (forfatterne til denne anmeldelse) arbejder med relativt forskellige emner - dansk kulturarv i Ghana og informationsteknologisk monitorering af udviklingsbistand - er vi, som det fremgår af ovenstående, inspireret af Helen Verrans tanker.

Således formår Helen Verrans begrebsapparat og ideer at gå hinsides både en relativistisk og universalistisk analyse af et dansk-ghanesisk samarbejde om et fælles kulturarvsprojekt, der ofte forstås og begrebsliggøres som „kulturmøder“. Faren ved et sådan favntag er netop, at man a priori opererer med to adskilte „,kulturer“, hvoraf „den anden“, i den universalistiske optik, skal kapacitetsopbygges for at blive som „den ene“, for at bruge et postkolonialt begrebspar. Og at man i den relativistiske variant i sidste instans kan ende med at omgå samarbejde, fordi man i tolerancens navn værner om grænserne, snarere end at se det hav af møder og spændinger, der i øvrigt ikke blot er mellem „danskerne“ og „ghaneserne“, som produktive størrelser. I stedet tilbyder antropologisk feltarbejde og analyse et studie af „her og nu“, hvor eksempelvis folk, ressourcer og klima kommer til syne på et væld af forskellige måder og konstant skaber fortider, fremtider, bygninger og prioriteringer. Med Helen Verrans arbejde som inspiration kan et dansk-ghanesisk samarbejde begrebsliggøres på en måde, der inspirerer til at se, hvordan „møder“" opstår, organiseres og materialiserer sig $i$ et fælles kulturarvsprojekt. På tilsvarende måde medvirker Helen Verrans arbejde i vores bearbejdning til at gøre hjemlige bureaukratier, statistik og databaser eksotiske, idet hendes arbejde inspirerer til at spørge, hvordan det overhovedet kan lade sig gøre at indsamle, klassificere og udveksle data, når tal gøres på så mange måder og derfor er så mange forskellige ting. Science and an African Logic og Helen Verrans øvrige arbejde er dog ikke anvendelsesorienteret, i den forstand at det kommer med færdigpakkede anvisninger til, hvordan man kan bruge ind- 
sigterne. Til gengæld tilbyder bogen og artiklerne ikke blot nye interessante begreber, men hjælper også en tålmodig læser til at overveje, hvad dennes eget ståsted er, fordi de tvinger overvejelser frem om, hvad der karakteriserer „,her og nu'et" i læserens eget arbejde.

\section{Note}

1. Tusind tak til Trine Søgaard Parmo Krog, som deltog i interviewet med Helen Verran i København, og som har hjulpet med værdifulde indspark sidenhen. Desuden takker vi Frida Hastrup, Julie Thiesen Winthereik og Casper Bruun Jensen for interessante samtaler og fine kommentarer til manuskriptet.

\section{Litteratur}

Latour, Bruno

2009 The Making of Law: An Ethnography of the Conseil d'Etat. Cambridge: UK Polity Press.

Mol, Annemarie

2002 The Body Multiple: Ontology in Medical Practice. Durham: Duke University Press.

Verran, Helen

$2001 \quad$ Science and an African Logic. Chicago: University of Chicago Press.

1999 Staying True to Laughter in Nigerian Class rooms. I: J. Law \& J. Hassard (eds.): After ANT: Complexity, Naming and Topology. S.136-55. Oxford: Blackwell Publishers. 